\title{
Öğrencilerin Okul ve Okul Müdürü Kavramlarına İlişkin Metaforik Algıları
}

\author{
Dr. Muharrem GENCER* \\ Milli Eğitim Bakanlığı, Burdur / Türkiye, \\ muharremgencer1978@hotmail.com, ORCID: 0000-0002-7212-8551
}

\section{Öz}

Bu çalışmanın amacı; öğrencilerin, okul ve okul müdürü kavramlarına ilişkin algılarını metaforlar aracılığıyla ortaya koymaktır. Nitel olarak tasarlanan bu çalışmada, fenomenolojik model kullanılmıştır. Çalışma grubunu, kolay ulaşılabilir durum örnekleme tekniği ile belirlenen 229 öğrenci oluşturmaktadır. Verilerin analizinde içerik analizi kullanılmıştır. Elde edilen araştırma bulgularına göre, okul kavramına ilişkin üretilen 69 metafor, 10 kategoride; okul müdürü kavramına ilişkin 76 metafor 10 kategoride toplanmıştır. Öğrencilerin okul kavramı için aile, ev ve ağaç; okul müdürü kavramı için beyin, komutan ve baba metaforlarını en sık kullandıkları görülmüştür. Metaforların ortak özellikleri dikkate alınarak oluşturulan kategorilerden okul kavramı için güven verici ortam ve bilgi sağlayıcı ortam kategorilerinde, okul müdürü için yönetim odağı ve yönlendirici/yol gösterici kategorilerinde en çok metafor üretildiği belirlenmiş̧tir.

Anahtar Kelimeler: Okul; Okul müdürü; Öğrenci; Alg1; Metafor. 


\title{
Metaphoric Perceptions of Students Towards
}

\author{
the Concepts of School and School Principal
}

\begin{abstract}
The purpose of this study is to reveal students' perceptions of school and school principal concepts through metaphors. In this qualitatively designed study, the phenomenological model was used. The study group consists of 229 students determined by convenience sampling technique. Content analysis was used in the analysis of the data. According to the research findings, 68 metaphors regarding the concept of school were collected in 10 categories and 76 metaphors regarding the concept of school principal were collected in 10 categories. It was seen that students most frequently used the metaphors of family, house and tree for the concept of school; brain, commander and father for the concept of school principal. Of the categories created by taking into account the common characteristics of metaphors, it was determined that the most metaphors were produced in the categories of reassuring environment and information provider environment for the concept of school and management focus and directing/guiding for the concept of school principal.
\end{abstract}

Keywords: School; School principal; Student; Perception; Metaphor.

\section{Extended Summary}

\section{Purpose}

Today, as competition grows more and more, the phenomenon of education, which makes the most important contribution to the development of societies, is gaining an increasing value. Therefore, the importance given to schools that is the building blocks of education system is rising. It is the school principals who effectively direct teachers, students and other educational staff to ensure that education in schools increases in quantity and quality (Başaran, 1994). Although their duties vary depending on the location and size of the school, the school principal is basically responsible for carrying out all kinds of functions of the school (Lunenburg and Ornstein, 2013).

As students spend a significant part of their time in school, perceptions about school and school principal take shape in their minds. Since these perceptions will be effective in guiding students' academic and social lives, metaphorical studies on education are needed. According to Hernes (2008), metaphors contribute to organizational studies as they are seen as a way of understanding the complex and paradoxical phenomena of organizations. It is 
considered that this study will contribute to the literature by analyzing the concepts of school and school principal in detail. In addition, determining how the school and school principals are perceived by students can give an idea of what can be done in schools in order to provide more qualified education. In this context, the aim of the study is to reveal students' perceptions towards the concepts of school and school principal through metaphors

\section{Method}

The study was carried out using phenomenology, one of the qualitative research patterns. The study group, which is determined by convenience sampling, consists of 229 students studying in two secondary schools in Yeşilova district of Burdur province in the first semester of 2019-2020 academic year.

There are two open-ended questions in the data collection tool to reveal the metaphors that students produce towards the concepts of school and school principal. Students were asked to complete the sentences "School is like ; because " and "School principal is like ; because .."

The data of the research was analyzed by content analysis. In parallel with the stages of content analysis, the process of analyzing and interpreting the metaphors revealed by the students was carried out by taking into account the following stages used by Yalçın, Aydoğdu-Özoğlu and Dönmez (2016): (1) Naming stage, (2) Elimination stage, (3) Recompile stage, (4) Category development stage, (5) Ensuring validity and reliability stage, (6) Calculating the frequencies of obtained metaphors stage.

\section{Results}

Students produced 69 metaphors regarding the concept of school. Metaphors were collected in 10 categories in terms of their common characteristics. The most frequently used metaphors towards the concept of school were ranged as family (29), house (25), tree (19), science house (14) and bird nest (13). It was determined that metaphors were mostly existed in reassuring environment, information provider environment and working and production center categories.

It was determined that 76 metaphors created by students regarding the concept of school principal were collected in 10 categories. Brain (27), commander (25), father (24), captain (19), and director (11) metaphors were identified as the most frequently produced metaphors towards the concept of 
school principal. It was seen that metaphors in the management focus, directing / guiding and protective / reassuring categories were used more.

\section{Discussion and Conclusion}

As a result of the study, the participants mostly used family and secondly home metaphors for the concept of school. This result may indicate that the school is perceived by the students as a peaceful and reassuring environment with love and respect. In the study, it was determined that the mostly used metaphors for the concept of school were collected in the category of reassuring environment. This may indicate that students feel safe at school. Similarly, in the study of Nalçacı and Bektaş (2012), it was determined that the participants produced metaphors mostly in the school category as a reassuring environment. Secondly, students frequently used metaphors related to the category of information provider environment regarding the concept of school. The results of research conducted on different study groups also support this finding (Saban, 2008; Özdemir and Akkaya, 2013).

According to the results of the study, students mostly used brain and secondly commander metaphors for the concept of school principal. This result may indicate that the school principal is perceived by the students as a strong leader. In the study, it was determined that the mostly used metaphors regarding the concept of school principal were produced in the category of management focus. In this category, the participants explained that school principals regularly organize and manage teachers, students and other school staff to make the school a learning center for them. Similarly, Yalçın and Enginer (2012) and Korkmaz and Çevik (2018) concluded that metaphors in the management category were frequently used by the participants. It was determined that the metaphors related to the category of directing/guiding were second frequently used regarding the concept of school principal. The results of other research also support this finding (Akın-Kösterelioğlu, 2014; Korkmaz and Çevik, 2018). However, Pesen, Kara and Gedik (2015) concluded that the participants produced the least metaphors in the category of being a directing/guiding.

In general, when the metaphors produced by the students regarding the concepts of school and school principal are evaluated, it can be said that the students have positive perceptions towards the school and the school principal. 


\section{Giriş}

Rekabetin her geçen gün daha da hız kazandığı günümüzde toplumların kalkınmasına en önemli katkıyı sağlayan eğitim olgusu giderek yükselen bir değer kazanmaktadır. Dolayısıyla eğitim sisteminin yapıtaşını oluşturan okullara verilen önem de artmaktadır. Eğitim sisteminde atölye konumunda olan okullar, bireylere önceden belirlenmiş eğitim amaçlarına uygun davranışlar kazandırmayı (Başaran, 1994), onların ve içinde bulundukları toplumun yaşam kalitesini artırmayı hedeflemektedir. Okullar kapsayıcı bir yaklaşımla ele alındığında farklı sosyo-ekonomik geçmişlere ve eğitsel başarı seviyelerine sahip öğrencilere hem akademik hem de akademik olmayan geniş bir eğitim deneyimi yaşatabilmektedir. Bu bağlamda okulların, öğrencilerin ve toplumun diğer fertlerinin refah düzeyini artırma ve toplumda eşitsizliği azaltmada etkin rol oynaması gerekir (Beck, 1990). Okul konusu üzerine çalışma yapan birçok araştırmacı, etkili okulların ortak özelliklerini açık ve net okul misyonu, yüksek beklentiler, mesleki liderlik, öğrenme firsatları, öğretim için yeterince zaman ayrılması, güvenli ve düzenli ortam, olumlu veli-okul ilişkileri, başarının sık sık izlenmesi, amaçlı öğretim ve pozitif pekiştirme olarak sıralamışlardır (Kirk ve Jones, 2004; Sammons, Hillman ve Mortimore, 1995). Eğitimin amaçlarına, öğrencilerin duyuşsal gereksinimlerinin karşılandığı okul ortamlarında daha etkili şekilde ulaşılmaktadır (Cooper, 1993). Bu nedenle öğrencilerin okul hakkındaki algı ve duyguları önem taşımaktadır.

Eğitim örgütü olan okullarda eğitimin nicelikçe ve nitelikçe artmasını sağlamak için öğretmenleri, öğrencileri ve diğer eğitim çalışanlarını örgütsel, yönetsel ve eğitsel amaçlar doğrultusunda güdüleyen, yönelten ve etkili biçimde çalıştıran okul müdürleridir (Başaran, 1994). Her ne kadar görevleri okulun bulunduğu yere ve büyüklüğüne göre değişim gösterse de okul müdürü temel olarak okulun her türlü işleyişini yerine getirmekten sorumludur (Lunenburg ve Ornstein, 2013). Bu nedenle okul müdürleri, kritik roller üstlenerek, hedeflerine ulaşma noktasında okula yön veren etkili kişilerdir. Okul müdürleri okul vizyonu ve hedefleri doğrultusunda öğretmenlerin daha verimli çalışabilmeleri için gerekli kaynakları temin edip doğru bir öğrenme süreci işleterek öğrenci öğrenmesine katkıda bulunabilirler (Leithwood ve Riehl, 2003).

Günümüz eğitim sistemlerinde müdürlerin, yalnızca öğretmenleri sınıflara yerleştirmeleri, ders araç ve gereçlerini temin etmeleri, öğrenci ve öğretmenlerin okula devam etmelerini sağlamaları yeterli görülmemektedir. $\mathrm{Bu}$ 
konuda yürütülen araştırmalar, okul müdürünün rollerinin önemli oranda değiştiğini, rol yelpazesinin çeşitlendiğini ve iş yükünün arttığını ortaya koymaktadır. Bu anlamda okul müdürlerinden üstlendikleri rollerin yanı sıra öğretim liderliği, öğretmenlerin profesyonel gelişimi, okuldaki süreçlerin yönetimi ile birlikte öğrenci ve öğretmenlerin denetlenmesi, karar verme, bütçe, finans, program geliştirme, okul-toplum ilişkisi gibi birçok rolü gerçekleştirmelerinin beklendiği görülmektedir (Balyer, 2012). Toplumun beklentilerinin artmasıyla beraber okul müdürleri, öğrenciler ile daha çok etkileşim içinde bulunmak durumunda kalmışlardır. Bu etkileşim öğrencilerin zihinlerinde okul müdürlerine yönelik çeşitli algılar oluşturmaktadır.

Öğrencilerin öğrenme sürecinde okul ortamı çok önemlidir. Pozitif bir okul ortamı, öğrencilerin okulu sevmelerine ve bunun sonucunda etkili öğrenmenin gerçekleşmesine yol açar. Pozitif okul ortamının oluşturulmasında okul müdürlerinin rolü büyüktür. Okulun, asıl hedef kitlesi belirli bir eğitim sürecinden geçen öğrencilerdir. Zamanlarının önemli bir bölümünü okulda geçirdikleri için öğrencilerin zihinlerinde okul ve okul müdürüne ilişkin algılar oluşur. Bu algılar, öğrencilerin akademik ve sosyal yaşantılarına yön vermede etkili olacağından eğitim ile ilgili metaforik çalışmalara ihtiyaç duyulmaktadır. Algıların olguların önüne geçtiği gerçeğinden hareketle, metaforlar yoluyla etrafımızda olup bitenleri daha iyi anlamlandırma imkânı bulabiliriz. Hernes'e (2008) göre metaforlar, örgütlerin karmaşık ve paradoksal olgularını anlamanın bir yolu olarak görüldüğü için örgüt çalışmalarına katkı sağlarlar.

Metafor kelimesi, meta (değiştirmek) ve pherein (taşımak) kelimelerinin birleştirilmesinden oluşan Yunanca metapherein sözcüğünden türetilmiştir (Levine, 2005). İki nesneyi veya kavramı birbirine bağlayan dilsel araç olan metaforlar, kişilerin bir deneyiminden diğerine aktarım veya karşılaştırma yapmak için iki farklı fikri ilişkilendirdikleri mecazi dil yapısı olarak kabul edilirler (Palmquist, 2001). Metaforlar, tutum ve davranışlarımızı etkileyerek karmaşık konuları anlaşılabilir görünümlerin içine sıkıştırırlar (Bolman ve Deal, 2008). Ayrıca yeni anlam üreten jeneratörler olarak işlev gördükleri için bilinen bir kavramın diğer kavramla bağını kurarak bilginin ortaya çıkmasını kolaylaştırırlar (Jensen, 2006). Shuell'in (1990, s.102) ifade ettiği gibi, "bir resim 1000 kelimeye bedelse, bir metafor da 1000 resme bedeldir. Bir resim sadece statik bir imge sağlarken, bir metafor ise bir olgu hakkında düşünmek için kavramsal bir çerçeve sunar.". Geçmişimize, günlük etkinliklerimize, bildiklerimize ve inandıklarımıza yeni anlamlar katan metaforlar (Lakoff ve 
Johnson, 1980), okul kavramını anlamlandırmada birçok araştırmacı tarafindan kullanılmıştır.

Cerit (2006), verilerini anket yoluyla elde ettiği çalışmasını ilköğretim öğrencileri, öğretmen ve yöneticileri ile gerçekleştirmiştir. Çalışmanın sonucunda okul kavramı için bilgi ve aydınlanma yeri, yetişme ve olgunluk, değişim ve gelişim ile aile ve takım metaforlarının kullanıldığını; kaotik bir ortam, hapishane, fabrika, ofis ve alışveriş merkezi gibi metaforların ise tercih edilmediğini tespit etmiştir. Demir (2007) Türk ve Amerikalı ortaokul öğrencileri ile yaptığı çalışmasında katılımcıların kültürlerine göre eğitim algılarında farklılıklar olduğu sonucuna ulaşmıştır. Türk katılımcılar okul ortamını; aile, bakım hizmetleri veren, psikolojik olarak besleyen, eğitsel olarak örnek ve fiziksel olarak cazip metaforları ile ifade etmişlerdir. Bunun yanında Türk katılımcılar tarafından okul, ileriki yaşamlarında yukarı doğru sosyal hareketlilik vaat eden, yaşama hazırlık ve istihdam olanağında temel bir ön koşul olarak görülmüsstür. Amerikalı katılımcıların büyük çoğunluğu ise okulu öğrencilerin hayatta kalmak için öğrenmek zorunda oldukları vahşi, kalabalık, kaotik, s1kıc1, acı verici, düzenlenmiş bir ortam olarak algılarken, bir kısmı neşe, şefkat, dahiliyet ve öğrenme yeri olarak görmüşlerdir. Mahlios ve Maxson (1998) çalışmalarında, üniversite öğrencilerinin ilkokul ve ortaokulda deneyimledikleri ve ideallerinde yer alan okul algılarını incelemişlerdir. Çalışmanın bulgularına göre katılımcılar ilkokul ve ortaokul deneyimlerini anlatan metaforları aile, takım, bahçe, sirk, hapishane, hayvanat bahçesi, sahne, topluluk ve fabrika olarak kullanmışlardır. Katılımcıların ideal okul kavramı için aile ve takım metaforlarını seçtikleri belirlenmiştir. Nalçacı ve Bektaş (2012) öğretmen adaylarının okula ilişkin algılarını metaforlar yoluyla inceledikleri çalışmalarında katılımcıların güven verici, sosyal ortam ve bilgi sağlayıcı kategorilerine ait metaforları sıklıkla kullandıkları sonucuna ulaşmışlardır. Özdemir ve Akkaya (2013) ise çalışmalarında genel lise öğrenci ve öğretmenlerinin okul ve ideal okul kavramlarına ilişkin algılarını metaforlar yoluyla ortaya çıkarmayı amaçlamışlardır. Çalışmanın bulgularına göre katılımcıların okula karşı olumsuz bir tutuma sahip oldukları; okulu gelişimi engelleyici, itaat zorunluluğu olan ve bu yüzden bir an önce terk edilmesi gereken bir yer olarak algıladıkları belirlenmiştir. Öğrenci ve öğretmenlerin ideal okul kavramı ile ilgili olarak okulu güven, mutluluk, heyecan ve bilgi veren, aydınlatan bir yer olarak görmek istedikleri tespit edilmiştir. Saban (2008), çalışmasında ilköğretim birinci kademedeki öğrenci, öğretmen ve öğretmen adaylarının okula ilişkin metaforik algılarını incelemiştir. Çalışmanın sonucunda da iki önemli bulguya dikkat 
çekmiştir. İlk olarak, okul kavramının bilgi ve aydınlanma yeri, yol gösterici ve yönlendirici, kültürlenme ve şekillendirme aracı ya da disiplin ve kontrol merkezi gibi farklı şekillerde ifade edilmesinden dolayı okul olgusunun sadece tek bir metaforla bir bütün olarak açıklanabilmesinin mümkün olmayacağıdır. Çalışmanın ikinci önemli bulgusu öğretmen ve öğretmen adaylarının büyük bir kısmının okulu kültürlenme ve şekillendirme aracı olarak görmeleridir.

Benzer şekilde okul müdürü kavramına yönelik alanyazında çok sayıda metaforik çalışmalar yer almaktadır. Bredeson (1985) okul müdürlerinin, okul yöneticiliğine ilişkin ürettikleri metaforları incelediği çalışmasında, metaforların amaca ulaşma, hayatta kalma ve vizyon olmak üzere üç başlık altında toplandığını belirlemiştir. Korkmaz ve Çevik (2018) ortaokul öğretmenlerinin okul müdürü kavramına yönelik algılarını inceledikleri çalışmalarında, katılımcıların okul müdürlerini ağırlıklı olarak yol gösterici ve lider biri olarak algıladıklarını saptamışlardır. Tüzel ve Şahin (2014), ilköğretim birinci kademe öğrencilerinin okul yöneticilerine ilişkin algılarını çizdikleri resimler ve kullandıkları metaforlar aracılığıyla ortaya çıkarmayı amaçlamışlardır. Çalışmanın bulgularına göre resimlerinde benzetme kullanan öğrencilerin tümünün olumlu figürler kullandığı belirlenmiştir. Okul müdürlerine ilişkin ürettikleri metaforların da çoğunlukla iyi bir insan ve yönetim kategorilerinde yer aldığı bulgulanmıştır. Yalçın ve Erginer (2012) ilköğretim ikinci kademedeki öğrenci, öğretmen, veli ve yöneticilerinin okul müdürü kavramına ilişkin metaforik algılarını incelemişlerdir. Öğrencilerin okul müdürlerini daha çok olumsuzluk unsuru, öğretmenler ve yöneticilerin yönlendirici ve yol gösterici, velilerin ise koruyucu ve güven verici olarak nitelendirdikleri sonucuna ulaşmışlardir.

Okul ve okul müdürü kavramlarının birlikte ele alındığı metaforik çalışmaların alan yazında sınırlı olduğu görülmektedir. Akan ve Yarım (2019) ilkokullarda öğrenim gören 3. ve 4. sınıf öğrencileriyle yaptığı çalışmalarında, öğrencilerin okulu öğretici, geliştirici bir yaşam alanı, bir eğlence ve oyun merkezi olarak gördükleri sonucuna ulaşmışlardır. Okul müdürünü ise bir yandan aile üyesi görüp severken diğer yandan öfkeli yapısı ve yönetsel ağırlığı nedeniyle korku unsuru olarak gördüklerini belirlemiş̧lerdir. Inbar (1996), tüm eğitim kademelerindeki eğitimci ve öğrenciler ile yapmış olduğu çalışmada katılımcıların okul müdürüne ilişkin üretmiş oldukları metaforların en çok "otoriter güç" temasında toplandığı sonucuna ulaşmıştır. Bu temada 
kullanılan metaforlardan bazıları başöğretmen, rahatsız edici patron, kral, süper hapishane müdürü, polis şefi, kükreyen aslan, baskılayıcı taş ve yüksek yargıç olarak sıralanabilir. Katılımcıların okula ilişkin üretmiş oldukları metaforlar, en çok "çerçeveli dünya" teması altında toplanmıştır. Bu tema altında toplanan bazı metaforlar sürgülü ve parmaklıklı kale, zorunlu ev, labirent, hapishane, kenar mahalle, askeri kamp ve eğitim hapishanesi olarak belirlenmiştir. Özdemir ve Orhan (2019) öğretmenlerin okul ve okul yöneticisi kavramlarına ilişkin algılarını metaforlar yoluyla inceledikleri çalışmalarında, okul kavramı ile ilgili kullanılan metaforların en çok "yaşam alanı olarak okul" temasında; okul yöneticisi kavramı ile ilgili metaforların "lider olarak okul yöneticisi” temasında toplandığını belirlemişlerdir. Okul ve okul müdürü kavramları ile yapılan çalışmalar incelendiğinde her iki kavramla ilgili olarak genellikle olumlu metaforların daha çok üretildiği, bazı çalışmalarda ise olumsuz metaforların da kullanıldığı söylenebilir.

Alanyazında ortaokul öğrencilerinin okul ve okul müdürü kavramlarına yönelik algılarının birlikte incelendiği çalışmaya rastlanılmamıştır. Bu nedenle çalışma, ortaokul öğrencilerinin hem okul hem de okul müdürü kavramları ile ilgili görüşlerini tespit edeceğinden alanyazına katkı sağlayacağı düşünülmektedir. Ayrıca okul ve okul müdürünün öğrenciler tarafindan nasıl alg1landığının belirlenmesi, okul uygulamaları için alternatif bakış açıları sunarak okullarda daha nitelikli eğitimin gerçekleşebilmesi için neler yapılabileceğine dair fikir verebilir. Diğer taraftan bu çalışma, öğrencilerin ürettikleri metaforlardan yola çıkarak, okul müdürlerinin olumlu algılanan davranışlarının devamının sağlanması ve olumsuz davranışlarının bırakılması sonucunu doğurabileceği için önemlidir. Bu bağlamda çalışmanın amacı, öğrencilerin okul ve okul müdürü kavramlarına ilişkin algılarını metaforlar aracılığıyla ortaya koymaktır. Çalışmada aşağıdaki sorulara cevap aranmıştır:

1. Öğrenciler okul ve okul müdürü kavramlarına ilişkin hangi metaforları üretmişlerdir?

2. Kavramlara ilişkin üretilen metaforlar hangi kategoriler altında toplanabilir?

\section{Yöntem}

Bu bölümde araştırma modeli, çalışma grubu, veri toplama aracı, verilerin toplanması ve analizine dair bilgiler yer almaktadır. 


\section{Araştırma Modeli}

Öğrencilerin okul ve okul müdürü kavramları hakkında sahip oldukları algıları metaforlar aracılığıyla belirlemeyi amaçlayan bu çalışma nitel araştırma desenlerinden fenomenoloji kullanılarak gerçekleştirilmiştir. Nitel araştırma en temel düzeyde kelimeler, resimler, imgeler gibi sayısal olmayan verilerin toplanmasına dayalı ampirik araştırma yaklaşımı olarak tanımlanır (Christensen, Johnson ve Turner, 2015). Fenomenolojik desende olgulardaki gerçekliğin tanımlanması amaçlanmakta ve katılımcılar tarafindan tecrübe edilmiş bir olgu ya da kavrama ilişkin psikolojik öz elde edilmeye çalışılmaktadır (Baş ve Akturan, 2013). Bu araştırmada da öğrencilerin eğitim ortamları olan okul ve okullarda sık iletişimde bulundukları okul müdürü kavramları birer fenomen olarak düşünülerek öğrencilerin bu kavramlar hakkındaki ortak algıları belirlenmeye çalışılmıştır.

\section{Çalışma Grubu}

Araştırmanın çalışma grubu, araştırmaya hız ve pratiklik kazandırmak amacıyla kolay ulaşılabilir durum örneklemesi yoluyla belirlenmiştir. Kolay ulaşılabilir durum örnekleme, katılımcı olarak yer alacak en yakın bireyleri seçmeyi ve gerekli örneklem büyüklügü elde edilene kadar bu sürece devam etmeyi içeren bir yöntemdir (Cohen, Manion ve Morrison, 2007). Çalışma grubunu 2019-2020 eğitim öğretim yılı 1. döneminde Burdur ili Yeşilova ilçesinde bulunan iki ortaokulda öğrenim gören 305 öğrenci oluşturmaktadır. Ancak 76 öğrencinin verileri okul ve okul müdürü kavramlarından birine ya da birden fazlasına ilişkin metaforlara uygun olmadığından araştırma kapsamı dışında tutulmasına karar verilmiş ve araştırma 229 öğrenciden toplanan verilerle yürütülmüştür. Araştırmaya katılan öğrencilerin 57'si (\%24.9) 5. sınıf, 65'i (\% 8.4) 6. sinıf, 58'i (\%25.3) 7. sinıf ve 49’u (\%21.4) 8. sinıfta öğrenim görmektedir. Ayrıca, 129’u (\%56.3) kız ve 100'ü (\%43.7) erkek öğrencilerden oluşmaktadır.

\section{Veri Toplama Aracı}

Araştırmada kullanılan veri toplama aracı iki bölümden oluşmuştur. Birinci bölümde katılımcıların demografik özelliklerini ortaya çıkarmaya dönük sorular yer almıştır. İkinci bölümde ise öğrencilerin okul ve okul müdürü kavramlarına yönelik ürettikleri metaforları belirlemek için açık uçlu iki soru bulunmaktadır. Öğrencilerden “Okul...........gibidir; çünkü..........” ve "Okul müdürü...........gibidir; çünkü..........” cümlelerini tamamlamaları istenmiştir. Katılımcılardan "çünkü" ifadesinden sonra gelen boşluğa açıklama 
yapmaları istenerek metaforun hangi amaçla kullanıldığı anlamlandırılmıştır. Yıldırım ve Şimşek'e (2005) göre mecazın kendisi tek başına betimsel ya da görsel gücünü yeteri kadar ortaya çıkartmayacaktır. Bunu takiben mutlaka "niçin" veya "neden" sorusu da sorulmalıdır. Mecazların asıl gücü, bu sıfatlarla ilgili sorudadır. Her birey, aynı mecaza farklı anlamlar yükleyebilir. Bir mecazı kullanırken hangi amaçla kullanıldığı ancak "niçin" sorusunun yanıtıyla elde edilebilir.

\section{Verilerin Toplanması ve Analizi}

Araştırmacı tarafından öğrencilere araştırma içeriği hakkında gerekli açıklamalar yapıldıktan sonra veri toplama aracı dağıtılmış ve onlardan kavramlar ile ilgili düşüncelerini yazmaları istenmiştir. Öğrencilere düşüncelerini yazmaları için ortalama 30 dakika süre tanınmış ve daha sonra formlar toplanmıştır. Katılımcıların okul ve okul müdürü kavramlarına ilişkin ortaya koydukları metaforlar içerik analizi tekniği ile çözümlenmiştir. İçerik analizinde temel amaç, toplanan verileri açıklayabilecek kavramlara ve ilişkilere ulaşmaktır. Böylece verilerin içinde saklı olan gerçekler ortaya çıkarılmaya çalış1lır (Yıldırım ve Şimşek, 2005). Bu bağlamda içerik analizinin merhalelerine paralel olarak öğrencilerin ortaya koydukları metaforların analiz edilmesi ve yorumlanması süreci, Yalçın, Aydoğdu-Özoğlu ve Dönmez (2016) tarafından kullanılan şu merhaleler dikkate alınarak gerçekleştirilmiştir:

1) Adlandırma merhalesi: Öğrencilerin okul ve okul müdürü kavramlarına ilişkin kullandıkları metaforları belirlemek amacıyla katılımcıların yanıtları incelenmiş ve geliştirdikleri bütün metaforlar alfabetik olarak listelenmiştir. $\mathrm{Bu}$ aşamada, öğrencilerin metaforları belirgin bir şekilde dile getirip getirmediğine bakılmış, metafor olarak nitelendirilmeyecek yanıtlar elenmiştir.

2) Eleme merhalesi: Eleme merhalesinde öğrencilerin ürettikleri metaforlar tekrar gözden geçirilmiştir. Kullanılan metafora ilişkin uygun gerekçe sunulmadığı, birden fazla kategoriye ait özellikleri içeren metaforlar üretildiği ve metafor yerine kavram ile ilgili kişisel düşünceler paylaşıldığg için 76 kağıt araştırma kapsamı dışında bırakılmıştır.

3) Tekrar derleme merhalesi: Geriye kalan 229 kâğıtta bulunan metaforlar tekrar alfabetik sıraya göre dizilmiştir. Metaforlardan bazıları örnek olarak sunulmuştur. Örnek olarak verilen ifadeleri kimin ürettiğine ilişkin kişisel bilgiler kodlanarak verilmiştir. Metaforun hangi öğrenciye ait olduğunu belirtmek amacıyla şu kodlamalar yapılmıştır: Katılımcıların sınıf düzeylerini temsil 
etmek için 5, 6, 7 ve 8 rakamları ve cinsiyetlerini belirtmek için E ve $K$ harfleri kullanılmıştır.

4) Kategori geliştirme merhalesi: Öğrencilerin okul kavramını açıklamak için ürettikleri 68 metafor ortak özellikleri açısından incelenerek 10 kategori altında toplanmıştır. Kategorilerin oluşturulmasında Özdemir ve Orhan (2019) ve Saban'ın (2008) bu konuda yapmış oldukları araştırmalardan yararlanılmıştır. Benzer şekilde öğrencilerin okul müdürü kavramına ilişkin geliştirdikleri 76 metafor ortak özellikleri bakımından incelenmiştir. Akın-Kösterelioğlu (2014) ve Yalçın ve Erginer'in (2012) bu konuda yapmış oldukları araştırmalardan yararlanılarak okul müdürü kavramı için 10 kategori oluşturulmuştur.

5) Geçerlik ve güvenirliğin sağlanması merhalesi: Nitel araştırmalarda toplanan verilerin ayrıntılı olarak rapor edilmesi ve araştırmacının sonuçlara nasıl ulaştı̆̆ını açıklaması geçerliğin önemli ölçütlerindendir (Yıldırım ve Şimşek, 2005). Araştırmanın geçerliğini sağlamak amacıyla, veri analiz süreci ayrıntılı olarak açıklanmıştır. Araştırmada elde edilen metaforlara ve oluşturulan kavramsal kategorilere ait bulgular kısmında detaylı şekilde yer verilmiştir.

Araştırmanın güvenirliğini sağlamak için, metaforların belirlenen kavramsal kategorileri temsil edip etmediğini belirlemek amaciyla uzman görüşüne başvurulmuştur. Veriler araştırmacının dışındaki bir uzman tarafından tekrar kodlanmış ve kodlamalar karşılaştırılmıştır. Karşılaştırmalarda görüş birliği ve görüş ayrıllğ 1 sayıları tespit edilmiş ve "Güvenirlik=[Görüş Birliği/(Görüş Birliği+Görüş Ayr1lığ1)]X100” formülünden (Miles ve Huberman, 1994) yararlanılarak kodlamalar arası güvenirlik oranları hesaplanmıştır. Güvenirlik oranları, okul metaforu için \%94 ve okul müdürü metaforu için $\% 92$ olarak hesaplanmıştır. Uyum yüzdesinin \%70'in üzerinde olması yeterli görüldüğünden (Yıldırım ve Şimşek, 2005) kodlama güvenirliğinin sağlandığ1 söylenebilir.

6) Elde edilen metaforların frekanslarının hesaplanması merhalesi: Bu merhalede okul ve okul müdürü kavramlarına yönelik olarak belirlenen kategorilerdeki metafor sayısı, metaforların frekans (f) ve yüzde değerleri (\%) hesaplanmıştır.

\section{Bulgular}

Okulu tanımlamak amaciyla kullanılan metaforlar ve bu metaforların ait oldukları kategoriler ile kategorilere ait frekanslar ve yüzde değerleri Tablo 1 'de verilmiştir. 
Tablo 1. Okul Kavramı ile İlgili Metaforlara İlişkin Bulgular

\begin{tabular}{|c|c|c|c|c|c|}
\hline Kategori & f & $(\%)$ & Metaforlar & f & $(\%)$ \\
\hline $\begin{array}{l}\text { Güven verici } \\
\text { ortam }\end{array}$ & 78 & 34.06 & $\begin{array}{l}\text { Aile (29), Cennet (1), Çatı (2), Ev } \\
\text { (25), Futbol takımı (5), Hastane (2), } \\
\text { Kalemlik (1). Kuş yuvası (13). }\end{array}$ & 8 & 11.77 \\
\hline $\begin{array}{l}\text { Bilgi sağlayıc1 } \\
\text { ortam }\end{array}$ & 55 & 24.02 & $\begin{array}{l}\text { Ağaç (19), Alışveriş merkezi (2), } \\
\text { Bakkal (2), Bilgi yuvası (6), Bilim } \\
\text { evi (14), Güneş (1), İnternet (1), Ki- } \\
\text { tap (5), Kütüphane (3), Tarihi eser } \\
\text { (1), Soba (1). }\end{array}$ & 11 & 16.18 \\
\hline $\begin{array}{l}\text { Çalışma ve üretim } \\
\text { merkezi }\end{array}$ & 30 & 13.10 & $\begin{array}{l}\text { Arıkovanı (5), Banka (1), Değirmen } \\
\text { (2), Fabrika (5), İnsan vücudu (4), } \\
\text { İnşaat (2), İşyeri (2) Hücre (2), Ku- } \\
\text { yumcu (2), Marangozhane (1), Or- } \\
\text { kestra (1), Sürücü kursu (1), Tarla } \\
\text { (2). }\end{array}$ & 13 & 19.12 \\
\hline $\begin{array}{l}\text { Disiplinli ve } \\
\text { sinırlayıcı ortam }\end{array}$ & 14 & 6.11 & $\begin{array}{l}\text { Hapishane (9), Karadelik (1), Kişla } \\
\text { (1), Labirent (1), Ordu (2). }\end{array}$ & 5 & 7.36 \\
\hline Araç & 12 & 5.25 & $\begin{array}{l}\text { Bilgisayar (1), Gemi (2), Kalem (1), } \\
\text { Otobüs (6), Uçak (1), Uzay mekiği } \\
\text { (1). }\end{array}$ & 6 & 8.82 \\
\hline $\begin{array}{l}\text { Geleceğe } \\
\text { hazırlayıcı ortam }\end{array}$ & 11 & 4.80 & $\begin{array}{l}\text { Havalimanı (1), Kapı (2), Köprü (1), } \\
\text { Kumbara (2), Merdiven (3), Sınav } \\
\text { (1), Yarışma (1). }\end{array}$ & 7 & 10.29 \\
\hline $\begin{array}{l}\text { Büyüme ve } \\
\text { olgunlaşma yeri }\end{array}$ & 10 & 4.37 & Bahçe (7), Hayat (2), Sera (1). & 3 & 4.41 \\
\hline Yaşam alanı & 9 & 3.93 & $\begin{array}{l}\text { Apartman (1), Bina (1), Dağ (1), De- } \\
\text { niz (2), Resim (2), Tiyatro sahnesi } \\
(1), \text { Ülke (1). }\end{array}$ & 7 & 10.29 \\
\hline $\begin{array}{l}\text { Yol gösterici } \\
\text { ortam }\end{array}$ & 8 & 3.49 & $\begin{array}{l}\text { Harita (2), Kutup yıldızı (1), Mum } \\
\text { (1), Pusula (1), Yıldız (1), Yol (2). }\end{array}$ & 6 & 8.82 \\
\hline Eğlendirici ortam & 2 & 0.87 & Kafeterya (1), Oyun parkı (1). & 2 & 2.94 \\
\hline
\end{tabular}

Tablo 1 incelendiğinde ortaokul öğrencileri tarafından okul kavramı ile ilgili olarak toplam 69 adet geçerli metafor üretilmiş ve bu metaforlar 10 kavramsal kategori altında toplanmıştır. Aşağıda üretilen metaforlardan oluşan kategoriler ve bu kategorileri temsil eden metaforları içeren ifadelere yer verilmiştir.

Güven verici ortam: Kategoride yer alan 8 farklı metaforu 78 (\%34.06) öğrencinin kullandığ 1 belirlenmiştir. Okul kavramı için en sık kullanılan aile (29) ve ikinci sırada sık kullanılan ev (25) metaforu bu kategoride yer almaktadır. Katılımcı görüşlerinden örnekler aşağıda sunulmuştur:

"Okul ailemiz gibidir. Çünkü ögretmenlerimiz anne ve babamız, arkadaşlarımız kardeş gibidir. Evde yardıma ihtiyacımı olduğunda anne ve babamız, okulda yardıma ihtiyacımı olduğunda öğretmenlerimiz bize yardim eder." $(5, \mathrm{~K})$. 
"Okul ev gibidir, çünkü hayatımızın yarısı evde yarısı okulda geçer. Buralar bizi kötülüklerden korur, huzurlu oluruz.” (8, E).

"Okul kuş yuvası gibidir. Çünkü yavru kuş uçup yuvadan gidene kadar anne ve baba kuş onu korur, besler. Okulda da biz mezun olana kadar ögretmenler ve müdür bizi korur." (K, 7).

"Okul kalemlik gibidir. Çünkü kalemlerin kaybolmaması için güvenli yer orasıdır. Bizim de okulda olmamı bizim yararımızadır.” (6, K).

Bilgi sağlayıcı ortam: Bu kategoride yer alan 11 farklı metaforu 55 (\%24.02) öğrencinin kullandığı belirlenmiştir. Okul kavramı için üçüncü sırada sık kullanılan ă̆aç (19) ve dördüncü sırada sık kullanılan bilim evi (14) metaforu bu kategoride yer almaktadır. Katılımcı görüşlerinden örnekler aşağıda sunulmuştur:

"Okul ağaç gibidir. Çünkü ağaçlar bize meyve verir. Okulda da sınıf geçtikçe farklı bilgiler alırız." (5, K).

"Okul bilim evi gibidir. Çünkü sınavlarda bize yararlı olacak bilgileri burada öğreniriz. Deneyler yaparı.” (7, E).

"Okul kitap gibidir, çünkü kitabın her sayfasında yeni bilgiler olduğu gibi her derste yeni bilgiler öğreniriz.” $(8, \mathrm{~K})$.

"Okul alışveriş merkezi gibidir. Alışveriş merkezine elimiz boş gireriz bir şeyler aldıkça elimiz dolar. Okula da geldiğimizde aklımızda bilgi yoktur. Okulda çok şey öğreniriz." (6, K).

Çalışma ve üretim merkezi: Bu kategoride kullanılan 13 farklı metaforu 30 (\%13.10) öğrencinin ürettiği belirlenmiştir. Aşağıda katılımcı görüşlerinden bazı alıntılar verilmiştir:

"Okul arı kovanı gibidir. Çünkü bütün arlar işbirliği içerisinde kovanda yaşarlar, bal üretirler. Okulda bütün öğretmenler iş birliği yaparak bizi yetiştirirler." (8, K).

"Okul değirmen gibidir. Çünkü buğday işlem görmemiş olarak değirmene gelir. Değirmenci buğdayı una dönüşürür ve un ekmek, pasta olmak için değirmenden çıkar. Öğretmenlerimiz bize bilgiler verince biz büyüdüğ̈̈müzde doktor, pilot, avukat olmak için okuldan mezun oluruz." (8, E).

"Okul fabrika gibidir. Fabrikalarda hammadde işçiler tarafindan işlenir. Bir ürün oluşur. Bize de öğretmenlerimiz bilgi verdikçe topluma yararlı duruma geliriz." $(6, \mathrm{~K})$. 
Disiplinli ve sinırlayıcı ortam: Kategoride yer alan 5 farklı metaforu 14 (\%6.11) öğrencinin kullandığı belirlenmiştir. Katılımcı görüşlerinden örnekler aşağıda sunulmuştur:

"Okul hapishane gibidir. Çünkü her gün sıkıcı dersler var. Teneffüsler çok kısa. Sabah okula geliyoruz. Akşama kadar dışarı çıkmak yasak." $(5, \mathrm{E})$.

"Okul ordu gibidir. Dokuz ay boyunca içinde kallyoruz askerlik gibi. Öğretmenler ve müdür komutanlar gibi bize emir veriyor.” $(6, \mathrm{E})$.

“Okul labirent gibidir. Çünkü okuldan çıkamıyoruz. Çıkmak isteğimizde müdür ve ögretmenler kızıyor." $(8, \mathrm{E})$.

Araç: Kategoride kullanılan 6 farklı metaforu 12 (\%5.25) öğrencinin ürettiği belirlenmiştir. Katılımcı görüşlerinden örnekler aşağıda sunulmuştur:

"Okul otobüs gibidir. Çünkü yolcular bilmediği yerleri şoföre sorar. Biz de anlamadığımız konuları ögretmenlere sorarız. Otobüste yolcular istediği durakta iner. Öğrenciler istediği kadar okur. Bazlları liseyi bitirir, bazllarl üniversiteyi bitirir.” (6, K).

"Okul gemi gibidir, biz de gemideki yolcular. Öğretmenlerimiz kaptan gibi bizi hangi yöne götüreceğini bilir.” (5, E).

Geleceğe hazırlayıcı ortam: Bu kategoride yer alan 7 farklı metaforu 11 (\%4.80) öğrencinin kullandı̆̆ı belirlenmiştir. Katılımcı görüşlerinden örnekler aşağıda sunulmuştur:

"Okul merdiven gibidir. Çünkü merdivende basamaklar vardır. Biz slnIf geçtikçe bir basamak yükseliriz. En sonunda meslek sahibi olmak için en üst basamă̆a çıkarız.” (7, K).

“Okul köprü gibidir. Çünkü bizim iyi meslek sahibi olmamız için tek yol odur. Karşlya geçmek için de tek yol köprüdür." (6, K).

Büyüme ve olgunlaşma yeri: Kategoride kullanılan 3 farklı metaforu 10 (\%4.37) öğrencinin ürettiği belirlenmiştir. Aşağıda katılımcı görüşlerinden bazı alıntılar verilmiştir:

“Okul bahçe gibidir. Öğrenciler küçük fidanların sulanıp yeşerdiği gibi bilgi aldıkça gelişir.” (6, K).

"Okul hayat gibidir. Çünkü hayatta zorluklarla karşılaştıkça insanlar olgunlaşıyor. Biz de okulda sinavlarla karşılaştıkça gelişiyoruz." (7, $\mathrm{K})$. 
Yaşam alanı: Kategoride yer alan 7 farklı metaforu 9 (\%3.93) öğrencinin kullandığı belirlenmiştir. Katılımcı görüşlerinden örnekler aşağıda sunulmuştur:

"Okul resim gibidir. Çünkü resimde yaşayan karakterler vardir. Okulda yaşayan karakterler de ögretmenlerimiz ve öğrencilerdir." (8, $\mathrm{K})$.

"Okul tiyatro gibidir. Çünkü ögrenciler yaşı geldiğinde okula gelir. Tiyatrodaki rol gibi okulda yaşar. Rolü bittiği zaman mezun olur gider." $(7, \mathrm{~K})$.

Yol Gösterici Ortam: Bu kategoride kullanılan 6 farklı metaforu 8 (\%3.49) öğrencinin ürettiği belirlenmiştir. Aşağıda katılımcı görüşlerinden bazı alıntılar verilmiştir:

"Okul harita gibidir. Çünkü haritaya bakarak yolumuzu bulabiliriz. Okul da bizi para kazanacağımız mesleğe götürür.” (8, E).

"Okul yol gibidir. Yolu bitirmek için sabırla yürürsek zorlukları aşarız. Yoldaki levhalar bize doğruyu gösterir. Öğretmenler gibi.” (8, K).

Eğlendirici ortam: Kategoride yer alan 2 farklı metaforu 2 (\%0.87) öğrencinin kullandığı belirlenmiştir. Katılımcı görüşlerinden örnekler aşağıda sunulmuştur:

"Okul kafeterya gibidir. Çünkü arkadaşlarımı ile sohbet ederiz. Okulda sikılmayız." (5, E).

"Okul oyun park gibidir. Teneffüslerde arkadaşlarımız ile oynar mutlu oluruz. Bazen derslerde öğretmenlerimiz bize oyun oynatır." (6, E).

Okul müdürünü tanımlamak amacıyla kullanılan metaforlar ve bu metaforların ait oldukları kategoriler ile kategorilere ait frekanslar ve yüzde değerleri Tablo 2'de verilmiştir.

Tablo 2 incelendiğinde, ortaokul öğrencileri tarafindan okul müdürü kavramı ile ilgili olarak toplam 76 adet geçerli metafor üretilmiş ve bu metaforlar 10 kavramsal kategori altında toplanmıştır. Tablonun sonunda geliştirilen metaforlardan oluşan kategoriler ve bu kategorileri temsil eden metaforları içeren ifadelere yer verilmiştir. 
Tablo 2. Okul Müdürü Kavramı ile İlgili Metaforlara İlişkin Bulgular

\begin{tabular}{|c|c|c|c|c|c|}
\hline Kategori & $\mathbf{f}$ & $(\%)$ & Metaforlar & f & $(\%)$ \\
\hline $\begin{array}{l}\text { Yönetim } \\
\text { odağ1 }\end{array}$ & 100 & 43.67 & $\begin{array}{l}\text { Albay (1), Apartman Yöneticisi (1), Başhe- } \\
\text { kim (2), Beyincik (1), Beyin (27), Belediye } \\
\text { başkanı (2), Cumhurbaşkanı (5), General } \\
\text { (4), Genelkurmay başkanı (1), Hastane mü- } \\
\text { dürü (1), Hücre çekirdeği (2), İçişleri ba- } \\
\text { kanı (1), Kaymakam (2), Kraliçe arı (2), } \\
\text { Kral (1), Komutan (25), Kulüp başkanı (1), } \\
\text { Orkestra şefi (1), Padişah (3), Omurilik (2), } \\
\text { Sinıf başkanı (3), Vali (1), Yönetmen (11). }\end{array}$ & 23 & 30.26 \\
\hline $\begin{array}{l}\text { Yönlendirici/ } \\
\text { Yol gösterici }\end{array}$ & 47 & 20.52 & $\begin{array}{l}\text { Bilgisayar faresi (1), Çoban (3), Eğitim } \\
\text { koçu (3), Göz (1), Kaptan (19), Pilot (1), } \\
\text { Rehber (3), Şoför (3), Takım kaptanı (3), } \\
\text { Teknik direktör (6), Telefon rehberi (1), } \\
\text { Trafik polisi (1), Usta (1), Ustabaş1 (1). }\end{array}$ & 14 & 18.42 \\
\hline $\begin{array}{l}\text { Koruyucu/ } \\
\text { Güven } \\
\text { verici }\end{array}$ & 37 & 16.15 & $\begin{array}{l}\text { Araba freni (1), Baba (24), Bahçıvan (2), } \\
\text { Bulut (1), Çatı (2), Çınar ağacı (1), Duvar } \\
\text { (1), Hâkim (1), Meyve bahçesinin sahibi } \\
\text { (1), Örümcek adam (1), Terazi (1), Trafik } \\
\text { lambası (1). }\end{array}$ & 12 & 15.79 \\
\hline Güç unsuru & 13 & 5.68 & Aslan (3), mafya babası (1), Patron (9). & 3 & 3.95 \\
\hline $\begin{array}{l}\text { Sert ve } \\
\text { baskicı }\end{array}$ & 7 & 3.06 & $\begin{array}{l}\text { Diktatör (1), Gardiyan (4), Hapishane mü- } \\
\text { dürü (1), Sinir topu (1). }\end{array}$ & 4 & 5.26 \\
\hline Vazgeçilmez & 7 & 3.06 & $\begin{array}{l}\text { Ağaç kökü (2), Başrol oyuncusu (1), Direk } \\
\text { (1), Evin temeli (3). }\end{array}$ & 4 & 5.26 \\
\hline $\begin{array}{l}\text { Bilginin } \\
\text { kaynağ1 ve } \\
\text { aktarıcıs }\end{array}$ & 6 & 2.62 & $\begin{array}{l}\text { Akıllı tahta (1), Bilim merkezi (1), Işık kay- } \\
\text { nağ1 (1), Kalem (1), Meyve ağacı (1), Öğ- } \\
\text { retmen (1). }\end{array}$ & 6 & 7.90 \\
\hline Sevgi unsuru & 5 & 2.18 & Dost (2), Fırın (1), Güneş (1), Sabır taş1 (1). & 4 & 5.26 \\
\hline Birleştirici & 4 & 1.75 & Çimento (1), Kalem kutusu (1), Vida (2). & 3 & 3.95 \\
\hline Çalışkan & 3 & 1.31 & Karınca (1), Kamyon (1), Temizlikçi (1). & 3 & 3.95 \\
\hline
\end{tabular}

Yönetim odağı: Bu kategoride yer alan 23 farklı metaforu 100 (\%43.67) öğrencinin kullandığ 1 belirlenmiştir. Okul müdürü kavramı için en sık kullanılan beyin (27) ve ikinci sirada sik kullanılan komutan (25) metaforu bu kategoride yer almaktadır. Katılımcı görüşlerinden örnekler aşağıda sunulmuştur:

"Okul müdürü beyin gibidir. Çünkü beyin vücudumuzdaki tüm organları yönetir. Onlardan sorumludur. Okul müdürü okuldaki ögretmenleri ve öğrencileri yönetir." $(8, \mathrm{~K})$.

"Okul müdürü komutan gibidir. Çünkü okul müdürü okuldaki herkesi yönetir. Komutan da askerlere emirler verir onlarl yönetir." (5, E).

"Okul müdürü yönetmen gibidir. Yönetmen oyunculart ve diğer çalışanlarl yönetir. Okul müdürü bizleri yönetir." $(6, \mathrm{~K})$. 
Yönlendirici/Yol gösterici: $\mathrm{Bu}$ kategoride yer alan 14 farklı metaforu 47 (\%20.52) öğrencinin kullandığı belirlenmiştir. Aşağıda katılımcı görüşlerinden bazı alıntılar verilmiştir:

"Okul müdürü kaptan gibidir. Çünkü kendisi denizleri çok iyi bilir ve buna göre gemidekilere yol gösterir. Okul müdürü de hayatı çok iyi bilir, bize yol gösterir." $(6, \mathrm{~K})$.

“Okul müdürü teknik direktör gibidir. Çünkü teknik direktör oyuncuların maça iyi çıkmasını sağlar. Okul müdürü ise sinavlarda başarılı olmamız için bize rehberlik eder." (8, E).

"Okul müdürü çoban gibidir. Çünkü çoban olmazsa koyunların düzeni bozulur. Nereye gideceklerini bilemezler. Okul müdürü çoban gibi öğrencilerin zarar görmesini önler." (7, K).

Koruyucu/güven verici: $\mathrm{Bu}$ kategoride kullanılan 12 farklı metaforu 37 (\%16.15) öğrencinin ürettiği belirlenmiştir. Okul müdürü kavramı için üçüncü sırada sık kullanılan baba (24) metaforu bu kategoride yer almaktadır. Katılımc1 görüşlerinden örnekler aşağıda sunulmuştur:

"Okul müdürü baba gibidir. Çünkü evde baba olmazsa kötülüklerden korunamayız. Babamız bize sahip çılkar. Müdür biz evlatlarını korur, bizim zarar görmememiz için uyarılarda bulunur.” $(6, \mathrm{~K})$.

"Okul müdürü örümcek adam gibidir. Örümcek adam masum insanların yardımina koşar. Okul müdürü örümcek adam gibi bize kötülük geleceği zaman hemen yardim eder." $(6, \mathrm{E})$.

“Okul müdürü araba fireni gibidir. Çünkü araba freni tehlikeli durumlarda arabayı durdurur. Okul müdürü fren gibi bizim iyiliğimiz için yaptığımı davranışlar tehlikeli ise bizi durdurur." $(8, \mathrm{~K})$.

Güç unsuru: Bu kategoride yer alan 3 farklı metaforu 13 (\%5.68) öğrencinin kullandığı belirlenmiştir. Katılımcı görüşlerinden örnekler aşağıda sunulmuştur:

"Okul müdürü patron gibidir. Çünkü iş yerinde en çok sözü dinlenen patrondur. Okulda ise herkes müdürün sözünü dinler.” $(6, \mathrm{E})$.

"Okul müdürü aslan gibidir. Ormanda birçok hayvan vardır. Bunların en güçlüsü aslandır. Okuldaki insanların en güçlüsü müdürdür." (8, $\mathrm{K})$.

Sert ve baskıc1: Bu kategoride kullanılan 4 farklı metaforu 7 (\%3.06) öğrencinin ürettiği belirlenmiştir. Kategoride yer alan bazı öğrenci açıklamaları şu şekildedir: 
"Okul müdürü gardiyan gibidir. Gardiyan gibi her şeyi görür. Okulda sorun çıkaranlara kızar." (7, E).

“Okul müdürü diktatör gibidir. Hiç kimse ona karlşamaz. Emirler verir. Yanlış yapanları cezalandırır." (7, E).

Vazgeçilmez: Bu kategoride yer alan 4 farklı metaforu 7 (\%3.06) öğrencinin kullandığı belirlenmiştir. Aşağıda katılımcı görüşlerinden bazı alıntılar verilmiştir:

"Okul müdürü evin temeli gibidir. Çünkü evin temeli olmazsa ev yerinde duramaz, ylkllır. Okul müdürü olmazsa okul olmaz.” (7, K).

"Okul müdürü ağaç kökü gibidir. Ăgacın kökü olmadan ağaç yaşayamaz. Ă̆acın kökü ăgacı ayakta tutar. Okulu ise müdür ayakta tutar." $(8, \mathrm{E})$.

Bilginin kaynağ1 ve aktarıcısı: Bu kategoride kullanılan 6 farklı metaforu 6 (\%2.62) öğrencinin ürettiği belirlenmiştir. Katılımcı görüşlerinden örnekler aşağıda sunulmuştur:

"Okul müdürü akallı tahta gibidir. Akillı tahtada bizim için gerekli tüm bilgiler vardır. Оnu açtığımızda bilgiler ögreniriz. Müdüre soru sorduğumuzda istediğimiz bilgileri ögreniriz." $(6, \mathrm{E})$.

“Okul müdürü bilim merkezi gibidir. Her şeyi bilir. Öğretmenler öğrenciler ondan çok şey ögrenir." $(5, \mathrm{~K})$.

Sevgi unsuru: Bu kategoride yer alan 4 farklı metaforu 5 (\%2.18) öğrencinin kullandığı belirlenmiştir. Kategoride yer alan bazı öğrenci açıklamaları şu şekildedir:
"Okul müdürü dost gibidir. Sorunlarımızı dinler. Bize yardımcı olmaya çalışır." (6, E).
"Okul müdürü güneş gibidir. Güneşin bitkilere ışık verdiği gibi bize sevgisini verir, içimizi ısitır." $(6, \mathrm{~K})$.

Birleştirici: Bu kategoride kullanılan 3 farklı metaforu 4 (\%1.75) öğrencinin ürettiği belirlenmiştir. Aşağıda katılımcı görüşlerinden bazı alıntılar verilmiştir:

"Okul müdürü çimento gibidir. Nasll çimento tuğlalar bir arada tutarsa okul müdürü de çocuklarl ve öğretmenleri bir arada tutar." (6, $\mathrm{K})$. 
“Okul müdürü vida gibidir. Vida parçaları birleştirir. Okul müdürü de ögrencilerin ve ögretmenlerin düzen içinde birlikte yaşamasını să̆lar." $(8, \mathrm{~K})$.

Çalışkan: Bu kategoride yer alan 3 farklı metaforu 3 (\%1.31) öğrencinin kullandığı belirlenmiştir. Katılımcı görüşlerinden örnekler aşağıda sunulmuştur:

“Okul müdürü kamyon gibidir. Okulun bütün yükünü o çeker. Omzundan hiç yük kalkmaz." (5, K).

“Okul müdürü karınca gibidir. Karıncalar kışlıkyiyeceklerini çıkarmak için çok çalışırlar. Okul müdürü ise öğrencilerin rahat etmesi için koşturur durur." (7, K).

\section{Tartışma ve Sonuç}

$\mathrm{Bu}$ araştırma, ortaokul öğrencilerinin okul ve okul müdürü kavramlarına ilişkin sahip oldukları metaforları belirlemek ve elde edilen metaforları belirli kavramsal kategoriler altında toplamak amacıyla yapılmıştır. Katılımcıların okul kavramına ilişkin oluşturdukları 68 metafor 10 kategoriye yerleştirilmiştir. Okul müdürü kavramına yönelik ürettikleri 76 metafor da 10 kategori altında toplanmıştır.

Çalışmanın bulgularına göre katılımcılar okul kavramı için en sık aile ve ikinci sırada ev metaforunu kullanmışlardır. Bu sonuç öğrenciler tarafindan okulun sevgi ve saygının yer aldığı, huzurlu ve güven verici bir ortam olarak algılandığını gösterebilir. Nalçacı ve Bektaş (2012), Ogurlu, Öpengin ve Hızlı (2015) ve Tulunay-Ateş'in (2016) çalışmalarında katılımcıların okulu tanımlamada en çok ev/aile metaforunu tercih ettikleri belirlenmiştir. Farklı çalışma gruplarında da aile ve ev metaforlarının sıklıkla kullanılması, okulların güvenilir ve samimi bir ortam olarak algılandığını açıklayabilir. Baker'ın (1991) okul gelişimi için öne sürdüğü dört kategoriden birisi de aile kategorisidir. Bu kategoride okul müdürlerinin, öğretmenlerin ve diğer okul personelinin öğrencilerin gereksinimlerine göre sorumluluğu paylaşarak onları korumaları gerektiğini belirtmiştir. Öğrenciler okul kavramı için üçüncü sırada ağaç ve dördüncü sırada bilim evi metaforlarını kullanmışlardır. Bu bulgu, öğrencilerin okullarını kendilerine gerekli bilgi-becerilerin kazandırıldığ 1 ve yeteneklerinin geliştiği ortam olarak algıladıklarını gösterebilir. Genel olarak okul kavramına ilişkin kullanılan metaforlar değerlendirildiğinde, öğrencilerin okula yönelik olumlu bir tutuma sahip oldukları söylenebilir.

Çalışmada okul kavramı ile ilgili en çok metaforun güven verici ortam kategorisinde üretildiği belirlenmiştir. Bu durum okulların psikolojik ve fiziki 
açıdan sağl1klı koşullara sahip olduğunu böylece öğrencilerin kendilerini burada güvende hissettiklerini gösterebilir. Benzer şekilde Nalçacı ve Bektaş'ın (2012) öğretmen adayları ile yaptı̆̆ çalışmalarında katılımcıların güven verici bir ortam olarak en çok okul kategorisinde metafor ürettiklerini belirlemiştir. Yine Özdemir ve Akkaya'nın (2013) genel lise öğrencileri ve öğretmenleri ile yaptıkları çalışmalarında okul için güven veren bir yer kategorisinin oluştuması katılımcıların okulu güvenli bir yer olarak gördüklerini desteklemektedir. Bu çalışmalardaki benzer sonuçlardan hareketle okullarda genellikle şiddetten ve kaygıdan uzak, saygı ve hoşgörü kültürünün hâkim olduğu söylenebilir. Öğrenciler okul kavramı ile ilgili olarak ikinci sırada bilgi sağlayıcı ortam kategorisi ile ilgili metaforları sıklıkla kullanmışlardır. Okulların amacının öğrencilerin meslek sahibi olması ve onların hayata hazırlanması için gerekli olan bilgilerin üretilmesi ve aktarılması olarak kabul edildiği düşünülebilir. Ayrıca okullarda genellikle sınavlara hazırlığa dayalı öğretim faaliyetleri gerçekleştirilir. Bu nedenle öğrencilerin, okulu sınavlarda kullanabilecekleri bilgileri edinmek amacıyla geldikleri yer olarak nitelendirdikleri de söylenebilir. Farklı çalışma grupları üzerinde yapılan araştırmaların sonuçları da bu bulguyu desteklemektedir (Nalçacı ve Bektaş, 2012; Özdemir ve Akkaya, 2013; Saban, 2008). Çünkü okullar, bilginin üretiminin ve aktarımının gerçekleştiği, akademik başarı üzerinde doğrudan etkili olarak kabul edilen kurumlardır. Öğrenciler okul kavramı ile ilgili olarak üçüncü sırada çalışma ve üretim merkezi kategorisi ile ilgili metaforları sıklıkla kullanmışlardır. Bu kategoride öğrencilerin genellikle okul müdürü ve öğretmenleri işbirliği içinde çalışanlar, kendilerini ise ürün olarak gördükleri anlaşılmaktadır. Özdemir ve Orhan (2019) ile Saban'ın (2008) çalışmalarında da bu bulguyla benzer şekilde okul ile ilgili üretilen metaforlar iş ve çalışma merkezi ve üretim merkezi kategorilerinde incelenmiştir. Çalışma ve üretim merkezi kategorisinden sonra öğrencilerin sırasıyla disiplinli ve sınırlayıcı ortam, araç, geleceğe hazırlayıcı ortam, büyüme ve olgunlaşma yeri, yaşam alanı, yol gösterici ortam ve eğlendirici ortam kategorilerinde yer alan metaforları kullandıkları belirlenmiştir. Bu kategorilerden sadece disiplinli ve sınırlayıcı ortam kategorisi olumsuz olarak nitelendirilebilir. Bu kategoride üretilen metaforlardan öğrencilerin okulu, zorla tutuldukları ve kendilerine sürekli emirler verilen ortam olarak algıladıkları anlaşılmaktadır. Oysa etkili öğrenme ve yaratıcılık, öğrencilerin başkalarına zarar vermediği sürece kendilerini rahat ve özgür hissettikleri ortamlarda gerçekleşebilir. Özdemir ve Akkaya'nın (2013) çalışmalarında ise bu çalışmadan farklı olarak genel lise öğrenci ve öğretmenlerinin okulu en 
çok sınırlandırıcı ve cezalandırıcı yer kategorisinde ele aldıkları belirlenmiştir. Bunun nedeni genel lise öğrencilerinin ortaokul öğrencilerine kıyasla yaşları gereği istenmeyen davranışları önlemek için uygulanan denetim ve düzene uymak istememelerinden kaynaklanabilir.

Çalışmanın sonuçlarına göre öğrenciler okul müdürü kavramı için en sık beyin ve ikinci sırada komutan metaforunu kullanmışlardır. Bu sonuç öğrenciler tarafindan okul müdürünün güçlü bir lider ve yönetici olarak algılandığını gösterebilir. Çalışmanın bu bulgusuyla benzer şekilde okul müdürünü tanımlamada Akan, Yalçın ve Yıldırım (2004) öğretmenlerin, komutan; Özgenel ve Gökçe (2019) üç ve dördüncü sınıf öğrencilerinin, lider; Turhan ve Yaraş (2013) ilköğretim birinci kademe öğrenci ve öğretmenlerinin, hakem metaforlarını sıklıkla kullandıkları sonucuna ulaşmışlardır. Farklı çalışma gruplarında okul müdürünün liderlik metaforları ile ifade edilmesi, okul müdürlerinin okulda verimliliği sağlayabilmek için liderlik davranışlarını sergilemelerinden kaynaklanabilir. Leithwood ve Riehl (2003) liderliğin, öğrenci öğrenmesi için tüm okul unsurlarının içinde yaklaşık dörtte birlik paya sahip olduğunu belirtmişlerdir. Öğrenciler okul müdürü kavramı için üçüncü sırada baba metaforunu kullanmışlardır. Bu metaforu kullanan öğrenciler, okul müdürlerinin tehlikelere ve zorluklara karşı kendilerini gözetip koruduğunu, ihtiyaçları ve sorunları ile ilgilendiğini vurgulamışlardır. Bu araştırmanın bulgusuyla benzer şekilde alan yazında okul müdürü kavramına ilişkin baba metaforunun sıklıkla kullanıldığı sonucuna ulaşılan çalışmalar mevcuttur (AkınKösterelioğlu, 2014; Çobanoğlu ve Gökalp, 2015; Turhan ve Yaraş, 2013). Farklı çalışma gruplarında baba metaforunun sık kullanılmasının nedeni kültürümüzde okul müdürü ve baba rollerinin benzerliğinden kaynaklanıyor olduğu düşünülebilir. Metaforlar genel olarak değerlendirildiğinde, ortaokul öğrencilerinin okul müdürüne yönelik olumlu algıya sahip oldukları söylenebilir.

Çalışmada okul müdürü kavramı ile ilgili en çok metaforun yönetim odağı kategorisinde kullanıldığı belirlenmiştir. Katılımcılar bu kategoride ürettikleri metaforlarda okulun kendileri için öğrenme merkezi olmasını sağlamak için okul müdürlerinin öğretmenleri, öğrencileri ve diğer okul çalışanlarını düzenli olarak organize edip yönettiğini açıklamışlardır. Okul müdürlerinin yönetim görevi, eğitim-öğretim faaliyetlerinin kalitesini doğrudan etkileyeceği için müdürlerin okuldaki yönetim işlerini bütün kaynakları etkili şekilde kullanarak gerçekleştirmeleri gerekir. Çalışmanın bu bulgusuyla benzer şekilde Akın-Kösterelioğlu'nun (2014) öğretmen adayları, Korkmaz ve 
Çevik'in (2018) ortaokul öğretmenleri, Yalçın ve Enginer'in (2012) ilköğretim okulu ikinci kademe öğrenci, öğretmen, veli ve yöneticileri ile yaptıkları çalışmalarında yönetim kategorisindeki metaforların katılımcılar tarafından sıklıkla kullanıldığı sonucuna ulaşmışlardır. Çalışmalarda benzer sonuçların çıkması okul müdürlerinin, toplumun okuldan beklentilerini karşılamak ve okulun hedeflerini gerçekleştirebilmek için okul işleyişinin düzenini sağlayarak, öğrenci ve öğretmenleri motive edip harekete geçirdiği söylenebilir. Öğrenciler okul müdürü kavramı ile ilgili olarak ikinci sırada yönlendirici/yol gösterici kategorisi ile ilgili metaforları sıklıkla kullanmışlardır. Katılımcılar, öğrencilerin hedeflerine ulaşması için okul müdürlerinin kendilerini ve öğretmenleri yönlendirdiğini belirtmişlerdir. Bu konu ile ilgili yapılan diğer araştırmaların sonuçları da bu bulguyu desteklemektedir (Akın-Kösterelioğlu, 2014; Korkmaz ve Çevik, 2018; Yalçın ve Enginer, 2012). Farklı çalışma gruplarında yapılan çalışmaların bulgularında da okul müdürleri için yönlendirici/yol gösterici metaforlarının kullanılması, okul müdürlerinin etkili eğitim-öğretimi sağlamak ve teşvik etmek amacıyla bütün eğitim paydaşlarını işbirliği içinde yönlendirdiğini gösterebilir. Günümüzde okul müdürlerinden bilimsel bilgiyi kullanarak öğretmen ve öğrencilerin mevcut yeteneklerini geliştirmeleri için önderlik etmeleri beklenmektedir. Okul müdürleri yeterli bilgi ve deneyime sahip olduklarında öğretmenleri ve öğrencileri özendirme araçları ile güdüleyerek yönlendirebilirler. Çalışmanın bulgusundan farklı olarak Pesen, Kara ve Gedik (2015) çocuk gelişimi bölümü ikinci sınıf öğrencileriyle yaptıkları çalışmalarında yönlendirici/yol gösterici olma kategorisinde en az metafor üretildiği sonucuna ulaşmışlardır. Bu çalışmadaki katılımııların yönlendirici/yol gösterici kategorisinde daha çok metafor kullanmalarının nedeni, mevcut eğitim kademelerinde okul müdürleri ile iletişim ve deneyimlerinin daha yoğun olmasından kaynaklanabilir. Öğrenciler, okul müdürü kavramı ile ilgili olarak üçüncü sırada koruyucu/güven verici kategorisi ile ilgili metaforları kullanmışlardır. Katılımcılar, okul müdürlerini kendilerini her türlü olumsuzluğa karşı koruyan ve gözeten kişiler olarak algılamaktadırlar. Öğrenciler, kendilerinin korunduğunu ve güvenli bir ortamda olduklarını algıladıklarında okula daha istekli gelirler ve performansları artar. Benzer şekilde Yalçın ve Erginer (2012) çalışmalarında, okul müdürlerinin çoğunlukla öğrenci ve öğretmenleri koruyan, okulda güven ortamı oluşturmak için çalışan kişiler olarak nitelendirildiğini belirtmişlerdir. Katılımcıların koruyucu/güven verici kategorisinden sonra sirasıyla güç unsuru, sert ve baskıcı, vazgeçilmez, bilginin kaynağ1 ve aktarıcısı, sevgi unsuru, birleştirici ve çalışkan kategorilerinde yer 
alan metaforları kullandıkları bulgusuna ulaşılmıştır. Bu kategorilerden sadece sert ve baskıcı kategorisi olumsuz olarak nitelendirilebilir. Bu sonuca göre, öğrencilerin okul müdürünü emirler veren, sinirli ve otoriter olarak alg1ladıkları anlaşılmaktadır. Balcı'nın (1999) çalışmasında katılımcıların okul müdürünü genellikle otoriter ve disipline edici gibi olumsuz mecazlarla tanımladıkları tespit edilmiştir. Oysa günümüzde toplumun okul müdürlerinden beklentileri onların baskıcı, bürokratik ve geleneksel rolleri yerine değişime ayak uyduran ve farklı yönetsel stratejiler kullanarak okul başarısını artıran davranışlar sergilemeleridir. Çünkü okulların en önemli ögelerinden biri olan okul müdürlerinin işlerini daha yaratıcı, işbirliğine dayalı ve profesyonelce yapmaları önemlidir.

Çalışmanın sonuçları değerlendirildiğinde ortaokul öğrencilerinin okul ve okul müdürü kavramları ile ilgili ürettikleri metaforların genellikle olumlu ifadelerden oluştuğu görülmüştür. Ancak okul için disiplinli ve sınırlayıcı ortam, okul müdürü için sert ve baskıcı kategorilerinde metaforların kullanılmasından yola çıarak okul ikliminin daha pozitif duruma getirilmesi önerilebilir. Sınıf ve okul kuralları belirlenirken öğrencilerin de karara katılımı sağlanabilir. Üniversite eğitiminde okul yönetimi derslerine ve uygulamalarına ağırlık verilmesi önerilebilir. Ayrıca mevcut eğitim çalışanları özellikle okul müdürleri katı ve bürokratik davranışlardan uzak durarak iletişim kanallarını daha etkin kullanabilirler. Bu çalışma ortaokul öğrencileri ile gerçekleştirilmiştir. İleriki çalışmalarda çeşitli eğitim kademelerinde; okul müdürü, öğretmen, öğrenci ve veli gibi katılımcılar ile okul ve okulu oluşturan ögelere ilişkin algıları belirlemeye yönelik çalışmalar yapılabilir.

\section{Kaynakça}

Akan, D., Yalçın, S. ve Yıldırım, İ. (2004). “Okul müdürü” kavramına ilişkin öğretmenlerin metaforik algiları. Elementary Education Online, 13(1), 169-179.

Akan, D. ve Yarım, M. (2019). İlkokul öğrencilerinin okul ve okul müdürü kavramlarına ilişkin metaforik algıları. Düzce Üniversitesi Sosyal Bilimler Enstitüsü Dergisi, 9(2), 223-233.

Akın-Kösterelioğlu, M. (2014). Öğretmen adaylarının okul yöneticisi kavramına ilişkin metaforik algıları. Zeitschriftfürdie Welt der Türken / Journal of World of Turks, 6(3), 115-133.

Baker, P. J. (1991). Mindful engagement: Metaphors for school improvoment. The Education Digest, 7, 32-35.

Balc1, A. (1999). Metaphorical images of school: School perceptions of students, teachers and parents from four selected schools. Yayınlanmamıs doktora tezi, Orta Doğu Teknik Üniversitesi Eğitim Bilimleri Enstitüsü. 
Balyer, A. (2012). Çağdaş okul müdürlerinin değişen rolleri. Ahi Evran Üniversitesi Kırşehir Eğitim Fakültesi Dergisi, 13(2), 75-93.

Baş, T. ve Akturan, U. (2013). Nitel araştırma yöntemleri NVivo 7.0 ile nitel veri analizi (2. baskı). Ankara: Seçkin Yayıncılık.

Başaran, İ. E. (1994). Türkiye ĕgitim sistemi. Ankara: Yargıcı Matbaası.

Beck, C. (1990). Better schools: A values perspective. New York: Falmer Press.

Bolman, D. ve Deal, T. (2008). Reframing organizations. San Francisco, CA: JosseyBass.

Bredeson, P. V. (1985). An analysis of the metaphorical perspectives of school principals. Educational Administration Quarterly, 21(1), 29-50.

Cerit, Y. (2006). School metaphors: The views of students, teachers and administrators. Educational Science: Theory and Practice, 6(3), 692-699.

Christensen, L. B., Johnson, R. B. ve Turner, L. A. (2015). Nitel ve karma yöntem araştırmaları. (A. Aypay, Çev.). Araştırma yöntemleri desen ve analiz içinde (400-433). Ankara: Anı Yayıncılık. (Orijinal çalışma basım tarihi 2014.)

Cohen, L., Manion, L. ve Morrison, K. (2007). Research methods in education (6. bask1). London: Routledge.

Cooper, P. (1993). Effective schools for disaffected students: Integration and segregation. London: Routledge.

Çobanoğlu, N. ve Gökalp, S. (2015). Öğretmen adaylarının okul müdürüne ilişkin metaforik algıları. Mustafa Kemal Üniversitesi Sosyal Bilimler Enstitüsü Dergisi, 12(31), 279-295.

Demir, C. E. (2007). Metaphors as a reflection of middle school students' perception of school: A cross cultural analysis. Educational Research and Evaluation, 13(2), 89-107.

Hernes, T. (2008). Understanding organization as process: Theory for a tangled world. London: Routledge.

Inbar, E. (1996). Free educational prison: Metaphors and images. Educational Research, 38(1), 77-92.

Jensen, D. F. (2006). Metaphors as a bridge to understanding educational and social contexts. International Journal of Qualitative Methods, 5(1), 36-54.

Kirk, D. J. ve Jones, T. L. (2004). Effective schools assessment report. San Antonio TX: Pearson Education.

Korkmaz, M. ve Çevik, M. S. (2018). Ortaokul öğretmenlerinin müdür kavramına ilişkin metaforik algıları. Kuramsal Eğitimbilim Dergisi, 11(4), 973-1002.

Lakoff, G. ve Johnson, M. (1980). Metaphors we live by. Chicago: University of Chicago Press.

Leithwood, K. A. ve Riehl, C. (2003). What we know about successful school leadership. Philadelphia, PA: Temple University Press.

Levine, P. M. (2005). Metaphors and images of classrooms. Kappa Delta Pi Record, 41(4), 172-175.

Lunenburg, F. C. ve Ornstein, A. C. (2013). Devlet ve eğitim. (G. Arastaman, Çev.), Eğitim yönetimi (6. baskı) içinde (209-263). Ankara: Nobel Publications. (Orijinal çalışma basım tarihi 2012.)

Mahlios, M. ve Maxson, M. (1998). Metaphors as structures for elementary and secondary preservice teachers' thinking. International Journal of Educational Research, 29, 227-240. 
Nalçacı, A. ve Bektaş, F. (2012). Öğretmen adaylarının okul kavramına ilişkin alg1ları. Ahi Evran Üniversitesi Kırşehir Eğitim Fakültesi Dergisi, 13(1), 239-258.

Ogurlu, Ü., Öpengin, E. ve Hızlı, E. (2015). Üstün yetenekli öğrencilerin okul ve öğretmene ilişkin metaforik algıları. Dumlupınar Üniversitesi Sosyal Bilimler Dergisi, 46, 67-83.

Özdemir S. ve Akkaya E. (2013). Genel lise öğrenci ve öğretmenlerinin okul ve ideal okul algılarının metafor yoluyla analizi. Kuram ve Uygulamada Ĕ̈itim Yönetimi, 19(2), 295-322.

Özdemir, T. Y. ve Orhan, M. (2019). Öğretmenlerin okul, okul yöneticisi ve öğrenci velisi kavramlarına yönelik metaforik algıları. Kuramsal Eğitimbilim Dergisi, 12(2), 701-726.

Özgenel, M. ve Gökçe, B. D. (2019). Metaphorical analysis of the perceptions of the primary school students on the concepts of "school, teacher and principal". International Online Journal of Educational Sciences, 11(1), 100-122.

Palmquist, R. A. (2001). Cognitive style and users' metaphors for the web: An exploratory study. The Journal of Academic Librarianship, 27(1), 24-32.

Pesen, A., Kara, İ. ve Gedik, M. (2015). Çocuk gelişimi bölümü 2. sınıf öğrencilerinin "müdür" kavramına ilişkin metafor algıları. Siirt Üniversitesi Sosyal Bilimler Enstitüsü Dergisi, 5, 28-48.

Saban, A. (2008). Okula ilişsin metaforlar. Kuram ve Uygulamada Eğitim Yönetimi. $55,459-496$.

Sammons, P., Hillman, J. ve Mortimore, P. (1995). Key characteristics of effective schools: A review of school effectiveness research. London: OFSTED.

Shuell, T. J. (1990). Teaching and learning as problem solving. Theory into Practice, 29, 102-108.

Tulunay-Ateş, Ö. (2016). Öğrencilerin öğretmen ve okul metaforları. International Journal of Contemporary Educational Studies, 2(1), 78-93.

Turhan, M. ve Yaraş, Z. (2013). Öğretmen ve öğrencilerin öğretmen, disiplin, müdür, sınıf kuralları, ödül ve ceza kavramlarına ilişkin metafor algıları. Fırat Üniversitesi Sosyal Bilimler Dergisi, 23(1), 129-145.

Tüzel, E. ve Şahin, D. (2014). İlköğretim birinci kademe öğrencilerinin okul yöneticilerine ilişkin metaforları. Adlyaman Üniversitesi Sosyal Bilimler Enstitüsü Dergisi, 17, 355-396.

Yalçın, M., Aydoğdu-Özoğlu, E. ve Dönmez, A. (2016). Öğretim elemanlarının araştırma görevlisi kavramına ilişkin metaforik algıları. Ĕgitim ve Bilim, 41(185), 19-32.

Yalçın, M. ve Erginer, A. (2012). İlköğretim okullarında okul müdürüne ilişkin metaforik algılar. Öğretmen Ĕ̈itimi ve Ĕgitimcileri Dergisi, 1(2), 229-256.

Yıldırım, A. ve Şimşek, H. (2005). Sosyal bilimlerde nitel araştırma yöntemleri. Ankara: Seçkin Yayıncılık. 